\title{
Influence of Different Levels and Concentration of Micronutrients on Growth and Yield of Jamun (Syzygium cumini Skeels.)
}

\author{
G.N. Hemavathi ${ }^{1}$, S.V. Patil ${ }^{2 *}$, G.S.K. Swamy ${ }^{3}$, R.L. Raghunath Reddy ${ }^{1}$, \\ K. Tulsiram ${ }^{1}$ and K.N. Sreenivas ${ }^{1}$ \\ ${ }^{1}$ College of Horticulture, Kolar, Karnataka, India \\ ${ }^{2}$ RHREC, UHS Campus, GKVK, Bengaluru, Karnataka, India \\ ${ }^{3}$ College of Horticulture, Mysore, Karnataka, India \\ *Corresponding author
}

\begin{tabular}{|l|}
\hline Ke y w or d s \\
Jamun (Syzygium \\
$\begin{array}{l}\text { cumini Skeels.), } \\
\text { Micronutrients }\end{array}$ \\
\hline Article Info \\
\hline $\begin{array}{l}\text { Accepted: } \\
\text { 20 December2018 } \\
\text { Available Online: } \\
\text { 10 January } 2019\end{array}$ \\
\hline
\end{tabular}

The field experiment was conducted on Influence of different levels and concentration of micronutrients on growth and yield of Jamun (Syzygium cumini Skeels.) The treatment combination of $0.50 \% \mathrm{ZnSO}_{4}+0.20 \%$ Boron has recorded maximum increment in plant height $(53.57 \mathrm{~cm})$, plant spread in $\mathrm{N}-\mathrm{S}$ direction $(48.47 \mathrm{~cm})$ and $\mathrm{E}-\mathrm{W}$ direction $(49.40 \mathrm{~cm})$. Maximum stem height $(0.44 \mathrm{~m})$, canopy height $(4.44 \mathrm{~m})$, inter nodal length $(2.80 \mathrm{~cm})$, number of new flushes $(256.60)$, leaf area $\left(74.00 \mathrm{~cm}^{2}\right)$, number of panicles per $\mathrm{m}^{2}$ in north (41.90), south (42.67) and west (38.33) direction, number of panicle per plant (223.33), number of flowers per panicle (55.67), length of flowering panicle $(16.50 \mathrm{~cm})$, minimum days taken from flowering to harvesting (85 Days), fruit set per panicle $(42.33 \%)$, fruit number per plant $(3767)$ and yield per plant $(48.63 \mathrm{~kg})$ was higher in $0.50 \% \mathrm{ZnSO}_{4}+$ $0.20 \%$ Boron. Maximum increase in fruit weight $(12.88 \mathrm{~g})$, fruit length $(25.88 \mathrm{~mm})$ and seed weight (2.55g) was recorded in $0.50 \% \mathrm{ZnSO}_{4}+0.20 \%$ Boron. Further, the quality parameters of fruits such as higher total sugar $(8.14 \%)$, reducing sugar $(6.54 \%)$ of fruits was significantly improved with the above said combination of micronutrients.

\section{Introduction}

Jamun is known to be an indigenous and important minor crop in India. It is a hardy fruit crop. Its tree is very tall, evergreen in semi-arid and partially deciduous under arid conditions. Jamun is a tree attaining a height of $25-30 \mathrm{~m}$ and a stem girth 3-4 m. It is a beautifully shaped tree and is grown for its delicious fruits, shade and windbreak on the bunds road side avenues. Jamun is a crosspollinated crop. This long lived tree bears fruits up to 60-70 years. Jamun belongs to the family Myrtaceae. It has recently attained importance as its fruit is appraised by the diabetic patients. Fruit crops have high potential and many uses, but they are not cultivating on commercial basis because of fewer varieties with long gestation period and the plants, which are grown by seed, need more care for fruiting.

It is widely grown in many parts of India from Indo-Gangetic plains in the North to Tamil 
Nadu in the South (Singh and Srivastava, 2000). It has recently attained importance as its fruit is appraised by the diabetic patients by traditional practitioners over many centuries and its various plant parts possess many pharmacological properties. Not only it has wonderful anti hyperglycemic properties, but it has also proven antioxidant, antibacterial, antigen toxic, anti-inflammatory and anti-HIV properties (Sagrawat et al., 2006). The plant is rich in compounds containing anthocyanins, glucoside, ellagic acid, isoquercetin, kaemferol and myrecetin. The seeds are claimed to contain alkaloid, jambosine, and glycoside jambolin or antimellin (Swamy et al., 2012).

Flowering and fruiting takes place in MarchApril and bear fruits from May to July. Inflorescences are arise from the leaf axils of branchlets. Flowers exhibit bisexual nature and light yellow in colour. Some jamun varieties put forth to second season in October. Jamun is cross pollinated tree. It is observed that fruit drop in jamun starts just after fruit set and continues up to maturity. Only $15-30 \%$ fruits reach maturity. The flower and fruit drop are found at three stages. The first drop takes place during bloom or shortly thereafter, this proves to be the harvest drop as about $52 \%$ of the flowers drop off after four weeks from flowering.

The jamun growers are constrained with the problem of irregular bearing or cropping periodicity as well as reduced fruit set and increased fruit drop which leads to considerable loss of their production potential in-turn leads to reduced yield. The micronutrients like zinc and boron play a vital role in fruit growth and development and their application is found effective to solve these problems. Keeping this in view the present study was conducted to evaluate the response of foliar application of micronutrients on growth and yield of jamun at the Regional
Horticultural Research and Extension Centre (RHREC), University of Horticultural Sciences, GKVK campus, Bengaluru, Karnataka-560065.

\section{Materials and Methods}

The present experiment was carried out during 2017-18 at Regional Horticulture Research and Extension Centre, University of Horticultural Sciences, GKVK campus, Bengaluru, Karnataka-560 065. Seven year old uniform plants of jamun was used which are spaced at $6 \mathrm{~m} \times 6 \mathrm{~m}$ (277 plants/ha). The experimental design used was Randomized Complete Block Design (RCBD) with 9 treatment 3 replications.

$\mathrm{T}_{1}$ : Control, $\mathrm{T}_{2}: 0.25 \% \mathrm{ZnSO}_{4}, \mathrm{~T}_{3}: 0.50 \%$ $\mathrm{ZnSO}_{4}, \mathrm{~T}_{4}: 0.10 \%$ Boron, $\mathrm{T}_{5}: 0.20 \%$ Boron $\mathrm{T}_{6}: 0.25 \% \mathrm{ZnSO}_{4}+0.10 \%$ Boron, $\mathrm{T}_{7}: 0.25 \%$ $\mathrm{ZnSO}_{4}+0.20 \%$ Boron, $\mathrm{T}_{8}: 0.50 \% \mathrm{ZnSO}_{4}+$ $0.10 \%$ Boron, $\mathrm{T}_{9}: 0.50 \% \mathrm{ZnSO}_{4}+0.20 \%$ Boron. The treatment was imposed at the time of emergence of new flush, flowering and fruit set stages. The micronutrients (zinc and boron) at required concentration were dissolved in the water and sprayed to jamun plants.

The observations on plant height, plant spread, girth, number of new flushes, number of panicles per plant, length and width of panicle, number of flowers per panicle, fruit set, fruit number, fruit yield were measured. The plant height was measured vertically from the ground to tip of the tree and expressed in centimeter. The tree spread was measured in both North to South and East to West directions using a measuring tape and expressed in meters. Canopy spread was recorded before initiation of experiment and at six months interval and subsequent measurements were taken at the time of harvest and the increase in canopy spread during the experiment was calculated. Girth of 
the stem was measured below and above the graft union at a distance of $30 \mathrm{~cm}$ from the union. Numbers of new flushes were counted in all four directions of plant and mean of them was expressed as the number of flushes. Numbers of new emerged panicles were counted in all four directions of plant and was expressed as the number of new flushes. Length and width of the flowering panicles were measured in all the directions.

Mean length and width of flowering panicle was calculated by measuring the length and width of twenty panicles in all the directions of the tree. The number of flowers per panicle was calculated by counting the number of flowers in panicles in all directions of the tree and mean was calculated. The total number of fruit set per panicle was recorded when fruits were in pea nut size in tagged panicle in all the four directions and mean was calculated. The total fruits harvested during the season were counted and expressed in numbers. The weight of harvested fruits was expressed in terms of kg per plant. This is referred as yield per plant.

\section{Results and Discussion}

The data on above parameters are given in table 1 to 5 and the results are discussed hereunder.

\section{Increment in plant height}

The maximum increment of plant height $(53.57 \mathrm{~cm})$ was observed in $\mathrm{T}_{9}\left(0.50 \% \mathrm{ZnSO}_{4}\right.$ $+0.20 \%$ Boron) in (Table 1). This indicated the positive combined effect of micronutrients on plant height. The higher increment in growth parameters might be due to the combined effect of zinc and boron, where zinc is known to increase the growth of plants by auxin biosynthesis and boron helps in cell division. Similar findings were reported by Yadav et al., (2017) in gauva.

\section{Plant spread}

The maximum plant spread from North South direction $(48.47 \mathrm{~cm})$ and East-West direction $(49.40 \mathrm{~cm})$ was recorded in $\mathrm{T}_{9}(0.50$ $\% \mathrm{ZnSO}_{4}+0.20 \%$ Boron) shown in (Table 2). Zinc is required for the synthesis of tryptophan, which is a precursor of auxin that might have resulted in increased apical growth and boron helps in cell division and cell elongation thus increased spread. Similar results were reported by Yadav et al., (2017) in guava and Kumar et al., (2017) in mandarin oranges.

\section{Girth of the stem above and below graft union}

The data related to stem thickness above and below graft union in different treatments were recorded in jamun $c v$. Chintamani (Table 3). Foliar application of zinc and boron did not alter the stem girth above and below the graft union in jamun.

\section{Number of new flushes}

Number of new flushes was differed significantly by foliar application of zinc and boron in jamun. The maximum number of new flushes (256.60) was recorded in $\mathrm{T}_{9}(0.50 \%$ $\mathrm{ZnSO}_{4}+0.20 \%$ Boron) in (Table 3). Zinc and boron are essential component of enzymes, responsible for nitrogen and carbohydrate metabolism respectively, there by resulting in increased uptake of nitrogen by the plant. Further, involvement of zinc in the synthesis of tryptophan, a precursor of indole acetic acid synthesis, consequently increased tissue growth and development.

Boron increases the phenolic compounds which regulate polar auxin transport. The increased auxin activity results in increased number of new flushes and vegetative growth characters. 
Table.1 Effect of zinc and boron on increment in plant height of jamun (3months after spraying)

\begin{tabular}{|c|c|c|}
\hline Treatment & Initial plant height (m) & Increment in plant height $(\mathrm{cm})$ \\
\hline $\mathbf{T}_{1}:$ Control & 4.09 & 35.73 \\
\hline $\mathrm{T}_{2}: 0.25 \% \mathrm{ZnSO}_{4}$ & 4.20 & 38.60 \\
\hline $\mathrm{T}_{3}: 0.50 \% \mathrm{ZnSO}_{4}$ & 4.28 & 43.07 \\
\hline $\mathrm{T}_{4}: 0.10 \%$ Boron & 3.98 & 41.17 \\
\hline $\mathrm{T}_{5}: 0.20 \%$ Boron & 3.80 & 39.27 \\
\hline $\mathrm{T}_{6}: 0.25 \% \mathrm{ZnSO}_{4}+\mathbf{0 . 1 0} \%$ Boron & 3.90 & 43.97 \\
\hline $\mathrm{T}_{7}: 0.25 \% \mathrm{ZnSO}_{4}+0.20 \%$ Boron & 4.00 & 44.53 \\
\hline $\mathrm{T}_{8}: 0.50 \% \mathrm{ZnSO}_{4}+0.10 \%$ Boron & 4.23 & 46.82 \\
\hline $\mathrm{T}_{9}: 0.50 \% \mathrm{ZnSO}_{4}+0.20 \%$ Boron & 4.42 & 53.57 \\
\hline S.Em \pm & 0.22 & 2.99 \\
\hline CD@ 5\% & NS & 8.95 \\
\hline
\end{tabular}

Table.2 Effect of zinc and boron on extent of plant spread in jamun (3months after spraying)

\begin{tabular}{|c|c|c|c|c|}
\hline Treatment & $\begin{array}{l}\text { Initial plant } \\
\text { spread in N-S } \\
\text { direction (m) }\end{array}$ & $\begin{array}{l}\text { Increase in plant } \\
\text { spread in N-S } \\
\text { direction }(\mathrm{cm})\end{array}$ & $\begin{array}{c}\text { Initial plant } \\
\text { spread in E-W } \\
\text { direction (m) }\end{array}$ & $\begin{array}{l}\text { Increase in plant } \\
\text { spread in E-W } \\
\text { direction }(\mathrm{cm})\end{array}$ \\
\hline $\mathrm{T}_{1}:$ Control & 4.27 & 39.53 & 3.60 & 44.33 \\
\hline $\mathrm{T}_{2}: 0.25 \% \mathrm{ZnSO}_{4}$ & 4.10 & 39.50 & 3.83 & 46.00 \\
\hline $\mathrm{T}_{3}: \mathbf{0 . 5 0} \% \mathrm{ZnSO}_{4}$ & 4.23 & 42.63 & 4.03 & 48.20 \\
\hline$T_{4}: 0.10 \%$ Boron & 4.33 & 43.20 & 3.87 & 39.33 \\
\hline $\mathrm{T}_{5}: \mathbf{0 . 2 0} \%$ Boron & 4.03 & 43.77 & 3.87 & 45.33 \\
\hline 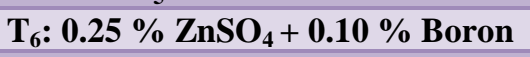 & 3.87 & 45.53 & 3.50 & 44.97 \\
\hline $\mathrm{T}_{7}: 0.25 \% \mathrm{ZnSO}_{4}+\mathbf{0 . 2 0} \%$ Boron & 4.23 & 46.03 & 4.20 & 46.00 \\
\hline $\mathrm{T}_{8}: \mathbf{0 . 5 0} \% \mathrm{ZnSO}_{4}+\mathbf{0 . 1 0} \%$ Boron & 3.93 & 47.53 & 3.63 & 48.73 \\
\hline $\mathrm{T}_{9}: \mathbf{0 . 5 0} \% \mathrm{ZnSO}_{4}+\mathbf{0 . 2 0} \%$ Boron & 4.00 & 48.47 & 3.73 & 49.40 \\
\hline S.Em \pm & 0.21 & 0.58 & 0.24 & 1.20 \\
\hline CD@ 5\% & NS & 1.74 & NS & 3.6 \\
\hline
\end{tabular}

Table.3 Effect of zinc and boron on stem thickness above and below graft union and number of new flushes in jamun (3months after spraying)

\begin{tabular}{|c|c|c|c|}
\hline Treatment & $\begin{array}{l}\text { Stem thickness Above } \\
\text { graft union }(\mathrm{cm})\end{array}$ & $\begin{array}{l}\text { Stem thickness below } \\
\text { graft union }(\mathrm{cm})\end{array}$ & $\begin{array}{c}\text { Number of new } \\
\text { flushes }\end{array}$ \\
\hline $\mathrm{T}_{1}:$ Control & 51.93 & 25.83 & 152.30 \\
\hline $\mathrm{T}_{2}: 0.25 \% \mathrm{ZnSO}_{4}$ & 49.24 & 26.10 & 205.23 \\
\hline $\mathrm{T}_{3}: 0.50 \% \mathrm{ZnSO}_{4}$ & 51.32 & 28.10 & 207.80 \\
\hline$T_{4}: 0.10 \%$ Boron & 49.10 & 25.83 & 198.33 \\
\hline $\mathrm{T}_{5}: 0.20 \%$ Boron & 50.93 & 28.60 & 208.20 \\
\hline $\mathrm{T}_{6}: 0.25 \% \mathrm{ZnSO}_{4}+0.10 \%$ Boron & 50.77 & 27.37 & 224.93 \\
\hline $\mathrm{T}_{7}: 0.25 \% \mathrm{ZnSO}_{4}+0.20 \%$ Boron & 53.87 & 30.43 & 232.77 \\
\hline $\mathrm{T}_{8}: 0.50 \% \mathrm{ZnSO}_{4}+0.10 \%$ Boron & 53.93 & 30.13 & 246.50 \\
\hline $\mathrm{T}_{9}: 0.50 \% \mathrm{ZnSO}_{4}+\mathbf{0 . 2 0} \%$ Boron & 54.60 & 31.27 & 256.60 \\
\hline S.Em \pm & 6.76 & 5.96 & 5.82 \\
\hline CD@5\% & NS & NS & 17.45 \\
\hline
\end{tabular}


Table.4 Effect of zinc and boron on flowering parameters in jamun

\begin{tabular}{|c|c|c|c|c|}
\hline Treatment & $\begin{array}{c}\text { Number of } \\
\text { panicles per } \\
\text { plant }\end{array}$ & $\begin{array}{c}\text { Number of } \\
\text { flower per } \\
\text { panicle }\end{array}$ & $\begin{array}{l}\text { Length of the } \\
\text { flowering panicle } \\
\text { (cm) }\end{array}$ & $\begin{array}{l}\text { Width of the } \\
\text { flowering } \\
\text { panicle }(\mathrm{cm})\end{array}$ \\
\hline$T_{1}$ : Control & 122.67 & 34.67 & 11.67 & 9.73 \\
\hline $\mathrm{T}_{2}: 0.25 \% \mathrm{ZnSO}_{4}$ & 180.00 & 37.67 & 12.10 & 9.34 \\
\hline $\mathrm{T}_{3}: 0.50 \% \mathrm{ZnSO}_{4}$ & 180.00 & 38.33 & 12.33 & 10.50 \\
\hline$T_{4}: 0.10 \%$ Boron & 127.00 & 43.00 & 13.30 & 9.97 \\
\hline$T_{5}: 0.20 \%$ Boron & 178.33 & 49.33 & 15.10 & 10.60 \\
\hline $\mathrm{T}_{6}: 0.25 \% \mathrm{ZnSO}_{4}+0.10 \%$ Boron & 157.33 & 45.00 & 14.33 & 11.03 \\
\hline $\mathrm{T}_{7}: 0.25 \% \mathrm{ZnSO}_{4}+\mathbf{0 . 2 0} \%$ Boron & 166.33 & 48.67 & 15.47 & 13.23 \\
\hline $\mathrm{T}_{8}: \mathbf{0 . 5 0} \% \mathrm{ZnSO}_{4}+0.10 \%$ Boron & 198.67 & 51.67 & 15.97 & 12.50 \\
\hline $\mathrm{T}_{9}: 0.50 \% \mathrm{ZnSO}_{4}+0.20 \%$ Boron & 223.33 & 55.67 & 16.50 & 11.60 \\
\hline S.Em \pm & 12.27 & 2.60 & 0.57 & 0.45 \\
\hline CD@ 5\% & 36.78 & 7.79 & 1.72 & 1.35 \\
\hline
\end{tabular}

Table.5 Effect of zinc and boron on Fruit set, fruit number per plant and Yield in jamun

\begin{tabular}{|c|c|c|c|c|}
\hline Treatment & $\begin{array}{c}\text { Fruit set per } \\
\text { panicle }(\%)\end{array}$ & $\begin{array}{c}\text { Fruit number } \\
\text { per plant }\end{array}$ & $\begin{array}{l}\text { Yield per } \\
\text { plant }(\mathrm{kg})\end{array}$ & $\begin{array}{l}\text { Increase in yield } \\
\text { over control } \\
(\%)\end{array}$ \\
\hline $\mathbf{T}_{1}$ : Control & 17.00 & 2266.00 & 23.70 & - \\
\hline $\mathrm{T}_{2}: 0.25 \% \mathrm{ZnSO}_{4}$ & 23.00 & 2499.00 & 24.74 & 4.38 \\
\hline $\mathrm{T}_{3}: 0.50 \% \mathrm{ZnSO}_{4}$ & 21.33 & 2494.33 & 25.55 & 7.80 \\
\hline$T_{4}: 0.10 \%$ Boron & 24.33 & 2949.00 & 30.81 & 30.00 \\
\hline$T_{5}: 0.20 \%$ Boron & 33.00 & 3026.67 & 31.66 & 33.58 \\
\hline $\mathrm{T}_{6}: 0.25 \% \mathrm{ZnSO}_{4}+\mathbf{0 . 1 0} \%$ Boron & 33.33 & 3215.00 & 36.39 & 53.54 \\
\hline $\mathrm{T}_{7}: 0.25 \% \mathrm{ZnSO}_{4}+\mathbf{0 . 2 0} \%$ Boron & 39.67 & 3225.33 & 37.34 & 57.55 \\
\hline $\mathrm{T}_{8}: 0.50 \% \mathrm{ZnSO}_{4}+0.10 \%$ Boron & 40.67 & 3222.33 & 39.42 & 66.32 \\
\hline $\mathrm{T}_{9}: 0.50 \% \mathrm{ZnSO}_{4}+0.20 \%$ Boron & 42.33 & 3311.33 & 42.59 & 79.70 \\
\hline S.Em \pm & 2.05 & 239.60 & 1.26 & - \\
\hline CD@ $@ 5 \%$ & 6.15 & 718.32 & 3.78 & - \\
\hline
\end{tabular}

\section{Number of panicles per plant}

The data related to number of flower panicles per plant after micronutrient application was significantly influenced by foliar application of zinc and boron (Table 4). The highest number of flower panicles (223.33) was recorded in $\mathrm{T}_{9}\left(0.50 \% \mathrm{ZnSO}_{4}+0.20 \%\right.$ Boron). This might be due to fact that zinc and boron, being important elements involved in reproduction, play an important role in enhanced flower bud initiation which leads to increased number of flowers and flowering panicles.

These findings are in agreement with the observations of Chandra and Singh (2015) in aonla who opined that zinc is the element present in activating several dehydrogenase and proteinase enzymes and involved in the 
biosynthesis of auxin, which promotes flowering and fruit setting of many plants.

\section{Length and width of the flowering panicle}

The data pertaining to foliar application of zinc and boron significantly influenced the length and width of the flowering panicle in jamun during 2017-18 (Table 4). Among different levels of foliar application, maximum length of flowering panicle (16.50 $\mathrm{cm})$ was recorded in $\mathrm{T}_{9}\left(0.50 \% \mathrm{ZnSO}_{4}+0.20\right.$ $\%$ Boron) and maximum width of flowering panicle $(13.23 \mathrm{~cm})$ was recorded in $\mathrm{T}_{7}(0.25$ $\% \mathrm{ZnSO}_{4}+0.20 \%$ Boron), zinc and boron induces maximum length of panicle due to combine effect of micronutrients involved in activation of enzymes, protein synthesis and photo assimilates as well as translocation for efficient cellular activity. Auxins activated by zinc might have increased the length and width of panicle through cell division and cell elongation in the shoot apex. Similar findings was reported by Venu et al., (2014) in kagzi lime.

\section{Number of flowers per panicle}

Highest number of flowers per panicle (55.67) was recorded (Table 4$)$ in $\mathrm{T}_{9}\left(0.50 \% \mathrm{ZnSO}_{4}+\right.$ $0.20 \%$ Boron) application of boron increases flower numbers and act its role in pollen tube germination and elongation and also regulates metabolism involved in translocation of carbohydrates, cell wall development and RNA synthesis. This is in conformity with the findings of Gurung et al., (2016) in darjeeling mandarin.

\section{Fruit set per panicle}

The fruit set per cent was significantly influenced by the foliar application of micronutrients in jamun (Table 5). The highest fruit set per cent $(42.33 \%)$ was observed in $\mathrm{T}_{9}\left(0.50 \% \mathrm{ZnSO}_{4}+0.20 \%\right.$ Boron) it might be the effect of boron which plays important role in developing reproductive organs (anthers, style, stigma and ovary), ovule development, pollen tube growth and fruit set.

\section{Fruit number per plant}

The highest fruit number per plant (3311.33) was observed (Table 5) in $\mathrm{T}_{9}\left(0.50 \% \mathrm{ZnSO}_{4}\right.$ $+0.20 \%$ Boron).Boron is a constituent of cell membrane and essential for cell division. These results may be comparable with the findings of Singh et al., (2007) in anola who have also reported that zinc application reduces the incidence of fruit drop because of the fact that it maintains the ongoing physiological and chemical processes related to inhibition of abscission there by increases fruit set and fruit number.

\section{Yield per plant}

The yield per tree was significantly influenced by foliar application of zinc and boron (Table 5). The highest yield $(42.59 \mathrm{~kg})$ was recorded in $\mathrm{T}_{9}\left(0.50 \% \mathrm{ZnSO}_{4}+0.20 \%\right.$ Boron). Zinc plays an important role in auxin biosynthesis which leads to reduction in fruit drop and higher fruit setting. Meanwhile, the application of zinc and boron might have caused rapid synthesis of protein and translocation of carbohydrate which ultimately led to increase in fruit weight which is directly correlated with total yield (Singh et al., 2012).

\section{References}

Chandra, R. and Singh, K.K., 2015, Foliar application of zinc sulphate, magnesium sulphate and copper sulphate on the yield and quality of aonla (Emblica officinalis Gaertn.) cv. "NA-7" under Garhwal Himalaya, J. Med. Plants Stud., 3(5): 42-45. 
Gurung, S., Mahato, S. K., Suresh, C. P. and Chetrri, B., 2016, Impact of foliar application of growth regulators and micronutrients on the performance of Darjeeling Mandarin. Am. J. Exp. Agric., 12(4): 1-7.

Kumar, N. C. J., Rajangam, J., Balakrishnan, K. and Sampath P. M., 2017, Influence of foliar application of micronutrients on yield and quality of mandarin orange (Citrus reticulata Blanco.) under lower pulney hills. Intl. J. of Agri. Sci., 9(17): 4151-4153.

Sagrawat, H., Mann, A. S. and Kharya, M. D., 2006, Pharmacological potential of Eugenia jambolana. Pharmacog Mag., 6(2): 96-105.

Singh, E. S. and Srivastava, A. K., 2000, Genetic diversity - Jamun (Syzygium cumini Skeels). Indian J. Hort., 45(3): 2.

Singh, J. K., Prasad, J. and Singh, H. K., 2007a, Effect of micro-nutrients and plant growth regulators on yield and physic-chemical characteristics of aonla fruits in $c v$. Narendra Aonla-10. Indian J, Hort., 64(2): 216-218.

Singh, P.C., Gangwar, R.S. and Singh, V.K., 2012, Effect of micronutrients spray on fruit drop, fruit quality and yield of aonla $c v$. Banarasi, Hort. Flora Research Spectrum, 1(1): 73-76.

Swamy, S. B., Thakor, N. J., Patil, M. M. and Haldankar, P. M., 2012, Jamun (Syzygium cumini, Skeels): A review of its food and medicinal uses. Food and Nutrition Sci., 3:1100-1117.

Venu, A., Delvadia, D. V., Sharma, L. K., Gardwal, P. C. and Makhmale, S., 2014, Effect of micronutrient application on flowering, fruiting and yield of Acid lime (Citrus aurantifolia L.) $c v$. Kagzi lime., Int. J. Trop. Agric., 32: 3-4.

Yadav, P., Sharma, J. R., Rupakshi, Baloda, S. and Kant, G., 2017, Influence of Foliar application of nutrients on growth, flowering, fruiting and yield of Guava (Psidium guajava) cv. L-49. Int. J. Pure App. Biosci., 5 (5): 1217-1222.

\section{How to cite this article:}

Hemavathi, G.N., S.V. Patil, G.S.K. Swamy, R.L. Raghunath Reddy, K. Tulsiram and Sreenivas, K.N. 2019. Influence of Different Levels and Concentration of Micronutrients on Growth and Yield of Jamun (Syzygium cumini Skeels.). Int.J.Curr.Microbiol.App.Sci. 8(01): 2966-2972. doi: https://doi.org/10.20546/ijcmas.2019.801.315 